Apuntes Universitarios, 2020: 10(4), octubre-diciembre ISSN: 2304-0335 DOI:https://doi.org/10.17162/au.v10i4.504

\title{
Instrucción de concienciación metacognitiva: un estudio de método mixto sobre el desarrollo de escritura y la motivación intrínseca de los estudiantes de EFL de la escuela secundaria
}

\author{
Metacognitive awareness instruction: a mixed method study on high school EFL \\ learners' writing development and intrinsic motivation
}

\author{
Mahdieh Akbarzadeh ${ }^{1 a}$, Massoud Tajadini ${ }^{2}$, Mehry Haddad Narafshan ${ }^{3}$ \\ Islamic Azad University, Kerman, $\operatorname{Iran}^{123}$ \\ Orcid ID: https://orcid.org/0000-0001-5220-357X \\ Orcid ID: https://orcid.org/0000-0001-5007-2289 \\ Orcid ID: https://orcid.org/0000-0001-9399-4750 3
}

Recibido: 03 de febrero de 2020

Aceptado: 19 de julio de 2020

\begin{abstract}
Resumen
El objetivo de este estudio fue investigar el impacto del uso de la instrucción de conciencia metacognitiva (MAI) en la habilidad de escritura de los estudiantes de EFL y su motivación intrínseca. Para seguir este objetivo, se diseñaron y propusieron tres preguntas de investigación. Las preguntas buscaban explorar el impacto del uso de la instrucción de conciencia metacognitiva en el desempeño de la escritura de los alumnos y también saber si se podía observar alguna relación significativa entre el desarrollo de la escritura de los alumnos y su motivación intrínseca. Para alcanzar estos objetivos, dos grupos de estudiantes de EFL de secundaria establecieron a los participantes del estudio. Para recopilar los datos del estudio, se utilizaron tres instrumentos: una prueba de homogeneización, pruebas previas y posteriores a la escritura y finalmente un cuestionario de motivación intrínseca desarrollado y examinado por (Payne, 2007). Los logros del estudio indicaron el impacto positivo del uso de MAI en la mejora de la escritura de los alumnos. Además, la motivación escrita de los alumnos aumentó significativamente. Finalmente, se pudo observar una relación significativa entre los niveles de escritura y la orientación de motivación de los alumnos.
\end{abstract}

Palabras clave: conciencia metacognitiva, escritura, motivación intrínseca, EFL.

\begin{abstract}
The goal of this study was to investigate the impact of using metacognitive awareness instruction (MAI) on EFL learners' writing skill and their intrinsic motivation. To follow this goal, three research questions were designed and proposed. The questions sought to explore the impact of using metacognitive awareness instruction on the writing performance of the learners
\end{abstract}


and also to know if any meaningful relationship could be observed between the learners' writing development and their intrinsic motivation. To these goals, two groups of high school EFL learners established the participants of the study. To collect the data of the study, three instruments were used: a test of homogenization, pre and post writing tests and finally intrinsic motivation questionnaire developed and examined by (Renee Payne, 2007). The achievements of the study indicated the positive impact of using MAI on the writing improvement of the learners. Moreover, the writing motivation of the learners significantly increased. Finally, meaningful relationship could be observed between the writing levels and the motivation orientation of the learners.

Keywords: metacognitive awareness, writing, intrinsic motivation, EFL.

\section{Introduction}

Recent interest in cognitive psychology has stressed the importance of taking account of what is happening in the learner's head and how they view learning since learners are not just an empty box, but are actively involved in the teaching-learning process and have their own attitudes towards teaching-learning components in terms of selecting an appropriate teaching method and its principles that can suit their personal properties. They have different needs when learning a foreign language and choose their own learning strategies and approaches.

All of this has led to an increasing awareness of the fact that individual differences in learning need to be accounted for, one important of which is the motivation the learners bring to the teaching situation and the other is the level of metacognitive awareness of the learners (Skehan, 1989; Riding \& Rayner, 2000; Ehrman, 1996; Dörnyei, 2005; Leaver et al., 2005; De Bot et al., 2005). Moreover, motivation plays a great and vital role in establishing psychological aspect of learning. In fact, its role is so large that sometimes it is hard to draw connections among motivation and specific activities such as math and science, or even language skills (Hidi \& Boscolo, 2007).

\section{Metacognition in EFL Context}

Metacognition is defined as cognition about cognition or simply thought about the thought, has become a major field of enquiry in cognitive and developmental psychology (Öz, 2005) and is recognized to affect cognition of human beings in various ways. The construct of metacognition has also been recognized as having a great importance in learning (Flavell, 1987). Metacognitive awareness means being aware of how you think. In the ELT classroom, it means being aware of how you learn. Developing metacognitive awareness is an important part of helping learners become more effective and, importantly, more autonomous. If learners are conscious of how they learn, then they can identify the most effective ways to learn more effectively with higher motivation. One of the most effective and easiest ways to develop metacognitive awareness is simply talking with learners about how they do things in the classroom, such as recording new words, reading a text, and laying out a page in their notebooks 
Metacognition means "thinking about one's own thinking". There are two aspects of metacognition: - reflection- thinking about what we know and self-regulation- managing how we go about learning (Flavell, 1979; Brown, 1987). Taking together, these processes make up an important aspect of learning and development. Developing these metacognitive abilities is not simply about becoming reflective learners, but about acquiring specific learning strategies as well. Metacognitive beliefs, metacognitive awareness, metacognitive experiences, metacognitive knowledge, metacognitive skills, executive skills, higher-order skills, metacomponents, metamemory are some of the terms that we are often using in association with metacognition. Metacognitive awareness means being aware of how you think. Metacognition is the awareness of one's thinking and the strategies one is using. It enables students to be more mindful of what they are doing, and why, and of how the skills they are learning might be used differently in different situations (Hacker, 2009).

The need for training in metacognitive awareness- raising comes from the value of metacognitive awareness in itself, for it "allows individuals to plan, sequence, and monitor their learning in a way that directly improves performance". For example, metacognitive knowledge has been found to aid the learners' choice of learning strategies, and if necessary, lead to their adjustments. By improving strategy use, metacognitive knowledge "plays a compensatory role in cognitive performance", and "may also compensate for low ability or lack of relevant prior knowledge (Schraw \& Denison, 1994).

\section{Intrinsic motivation}

Among the studies of the last decade, Deci and Ryan's self-determination theory of intrinsic motivation has influenced people in second and foreign language education (Dornyei, 2001; Noels, 2009; Noels et al., 2000; Wu, 2003). Probably, no one would argue against the following assertions of their theory (Deci \& Ryan, 1985), "They [Children] are unendingly curious, and they want to see the effects of their actions. Children are intrinsically motivated to learn, to undertake challenges, and to solve problems". And probably nor with their further claim: "To achieve self-determination, one must provide informational structures, ones that provide choice and competence feedback in the absence of pressure for specific performance". However, there is plenty of evidence from the EFL classroom to suggest that Deci and Ryan's thesis is significant but accounts only for part of the whole of intrinsic motivation, and therefore is, in a very real sense, limited in its practical applications.

\section{Flavell's Metacognition Theory}

Flavell (1979) viewed metacognition as learners' knowledge of their own cognition, defining it as "knowledge and cognition about cognitive phenomena". Metacognition is often referred to in the literature as 'thinking about one's own thinking', or as 'cognitions about 
cognitions'. It is usually related to learners' knowledge, awareness and control of the processes by which they learn and the metacognitive learner is thought to be characterized by ability to recognize, evaluate and, where needed, reconstruct existing ideas. Flavell's definition was followed by numerous others, often portraying different emphases on or different understanding of mechanisms and processes associated with metacognition.

According to the classic models, metacognition primarily consists of metacognitive knowledge (a declarative component) and regulation (a procedural component). Metacognitive knowledge refers to the knowledge about cognitive tasks, strategies and knowledge learners possess about themselves and people (Flavell, 1979). Regulation refers to the monitoring and control of one's cognitive processes during learning (Nelson \& Narens, 1990). In addition to these two prime components, recent findings show that metacognitive knowledge requires competence in using it (Corsale \& Ornstein, 1980; Schneider, 1985). Use of learning strategies is certainly a necessary component. Another major component is evaluation of or reflection on the result of one's learning, and experience. This metacognitive activity is an overall judgment of the product of a learning experience. It provides feedback to the learner on the selection and use of strategies leading to the refinement of one's metacognitive knowledge (Flavell, 1979; Schunk \& Ertmer, 1999).

\section{Metacognitive awareness in writing}

After the shift of paradigm towards progressive education and under the influence of cognitivism, education witnessed a marked emphasis on experiential learning (Gold et al., 2012) and problem solving (Mohanty, 2007). There has been a move toward process-oriented theories of writing which is, as Hairston claims, a paradigm shift in composition theory. In the new perspective, writing is viewed as a process of creation of meaning in which the writer gets involved in the recursive process of preparing the draft, revising and checking.

Under the influence of cognitive psychology on models of writing in early 1980s, the writers' mental processes gained prominent importance (Johns, 1990). In a short time, terms which had been borrowed from cognitive psychology found their place in the description of writers' mental processes. This trend gave birth to process-based models of writing. These models began to examine anew the act of composing. Among these models the most notable ones were developed by (Bereiter \& Scardamalia, 1987). Both models consider writing as problem solving act and a higher order mechanism which deal with the constraints while writing.

In Hayes \& Flower model (1980), it is assumed that writing is basically a problemsolving activity. Problem solving in this model means that the writer has to tackle the ongoing problem of formulating, organizing, and producing text. To put it simply, the problem for a writer is the act of producing the text for which he has to set goals and find a solution. To do 
so, based on Hayes \& Flower's model, writers has to constantly make decisions regarding their cognitive recourses (Wong, 1991). This necessitates the use of a higher order process which seems to control cognitive processing. In Hayes \& Flower model (1980), the monitor assumes such a responsibility and checks the progress of planning, translating and reviewing. Therefore, although not explicitly stated in the model, the monitor plays the role of metacognitive awareness.

The goal of this study was assisting the learners in the writing class to enhance their metacognitive awareness and consider its impact on the writing skill and intrinsic motivation of high school EFL learners. The goal was introducing the teaching procedures in the writing class being based on improving and fostering the metacognitive awareness of the learners.

\section{Research Questions}

To investigate the impact of metacognitive awareness in the writing class, the following three directional questions were raised:

1. What is the impact of metacognitive instruction on high school EFL learners' writing skill?

2. What is the effect of metacognitive instruction on high school EFL learners' intrinsic motivation?

3. Is there any meaning relationship between high school EFL learners' writing development and intrinsic motivation?

\section{Methodology}

\section{Participants}

The population of the study was composed of all high school learners in a school in Kerman, a city in the south east of Iran. The mother tongue of all learners was Farsi, with six years of studying English at high school level. They were all females, aged 16 to 18 . To homogenize the population, Basic Oxford Placement Test (2003) was administered and a sample of 46 made up the subjects who established the experimental group (EG: $n=22$ ) and the other control group (CG: $n=24)$. The researcher used availability sampling procedures in order to select the participants of the study.

To explore the relationship between the levels and the intrinsic motivation of the learners, based on the posttest scores of writings, the researcher classifies the learners of each group into two groups of high and low. Based on (Brown, 2005), the learners who had obtained $70 \%$ of the score were considered as high, and below it was classified as low. As a result, $69 \%$ of the learners in the EG were estimated to be high and the other $31 \%$ were classified as low. Of the CG, $45 \%$ were identified to be high and other $55 \%$ were classified as low. 


\section{Instrumentation}

In order to collect the data of the study, three instruments were used: test of homogenization, writing test, and writing intrinsic motivation questionnaire. Oxford Basic Test (2002) was used to homogenize the participants of the two groups. The next instrument was implementing writing test that was used both as pre and posttest in order to tap the writing level of the participants both at the beginning of the study and at the end after they had received the treatment. The test condition in terms of the allotted time, topic and scoring strategies were kept the same for both groups.

To improve the reliability of the writing scores, the researcher increased the number of raters to two (Brown \& Abeywickrama, 2010; Brown, 2005; Heaton, 1988; Hamp-Lyone, 2000) and thus each candidate's paper was assessed by two independent raters as well as the researcher herself. In addition, the raters were instructed by the researcher to follow a holistic or impression approach in rating the subjects' papers (Heaton, 1988; Fulcher \& Davidson, 2007).

To estimate the reliability of the scores offered by the three different raters, internal consistency of the scores were estimated using Spearman Correlation. To examine the learners' attitudes of the two groups on writing motivation, Writing Motivation Questionnaire (RMQ) was used. This questionnaire sought to estimate the intrinsic writing motivation of the learners. To this goal, the RMQ developed and examined in a study by (Payne, 2007) was used. Originally, it was a 37-item questionnaire using five-point Likert scale. The participants of both groups received the translated version of questionnaire, once before the study began and next at the end of the experiment when they had received the treatment. Of the 37-items of the questionnaire, 6 ones which were not related to this study were eliminated since they were about on-line writing activities as well as academic purposes that were not true for the high school learners of this study. Thus, the overall number of items of the questionnaire decreased to 31 .

To estimate the content validity of the questionnaire after being translated, it was back translated into English by an expert of translation and in several cases, some problems were observed that were removed and the edited version was used. To estimate the reliability of the questionnaire, the researcher used Chronbach's Alfa. It is an approach, as (Brown \& Hudson, 2003) discussed, to establishing reliability using a formula studying the relationship between item numbers of the questionnaire, variance of the total scores, and the proportion of the examinees who responded positively or negatively. Finally, it was proved to be reliable at .89 that was considered high enough.

\section{Metacognitive strategy teaching}

To present metacognitive strategies, the teacher explained what the strategy was, why it 
was a useful, and how and when it was to be used. Thus, the teacher incorporated three guidelines for EFL learners in her writing class. The first step was explicit instruction. As Salehi \& Farzad (2003) emphasized the important role metacognition plays in academic learning, and recommended direct instruction as one effective classroom practice that would help students to develop their metacognitive awareness. To this goal, the teacher summarized five key features which focused on explanations of how to learn metacognitively.

The second step was scaffolded instruction. The instructional goal for the students was to be able to self-regulate their own learning eventually without external support. Thus, the teacher in this step adopted scaffolded instruction to provide students with guided practice until their metacognitive strategies moved toward an automatic state. Scaffolding involves providing support to students to bridge the gap between what they can do on their own and what they can do with guidance from more competent others including teachers and peers.

As the final step, the teacher paid attention to the fact that metacognitive instruction needed to be an integral part of the instructional objectives and could be achieved within a long time of practice and activities. Thus, the writing class was exposed to the metacognitive awareness procedures over an entire school year. It was basically important in this study that the teachers had to implement metacognitive instruction in her classroom with a lot of patience. Garner (1988), Hartman (2001), Salehi \& Farzad (2003), and Sitko (1998) all advise that metacognitive instruction takes up a great deal of class time, and that sometimes students' progress and improvement are hard to be observed. Thus, both teacher and students needed much patience and persistence to practice the series of teaching activities.

\section{Results}

\section{Data of pre and post writing tests}

Table 1

Data of pre and post-test of writing for the CG

\begin{tabular}{lccccc}
\hline & N & Minimum & Maximum & Mean & Std. Deviation \\
\hline Pretest of CG & 24 & 5.00 & 12.00 & 7.4583 & 1.81729 \\
Posttest of CG & 24 & 7.00 & 15.00 & 10.8333 & 2.09900 \\
\hline
\end{tabular}

The Table 1 presents the data of pre and posttests of the CG. The mean for the pretests is 7.45 that increases to 10.83 for the posttest.

Table 2

Data of pre and post-tests of writing for EG

\begin{tabular}{cccccc}
\hline & N & Minimum & Maximum & Mean & Std. Deviation \\
\hline Pretest for EG & 22 & 5.00 & 15.00 & 9.5455 & 2.55841 \\
Posttest for EG & 22 & 9.00 & 17.00 & 14.7727 & 2.42864 \\
\hline ISSN 2312-4253(impresa) & & & & & 195
\end{tabular}


The Table 2 offers the pre and posttests data of the EG. The mean for the pretest is calculated to be 9.54 that increases to 14.77 for the posttest.

Table 3

Paired samples test for the CG

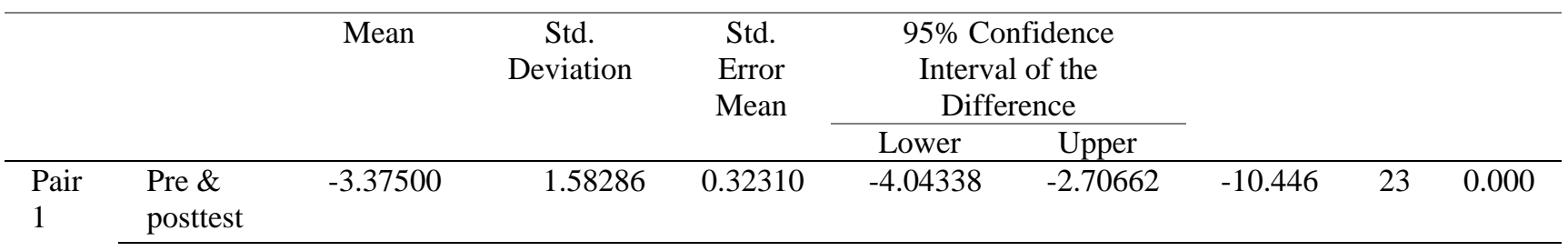

The Table 3 presents paired samples T test for the CG. The $\mathrm{p}$ value $=0.000<0.05$ at 23 degree of freedom. The data indicates meaningful relationship between the pre and posttests of the two performances of the CG.

Table 4

Paired samples test for the EG

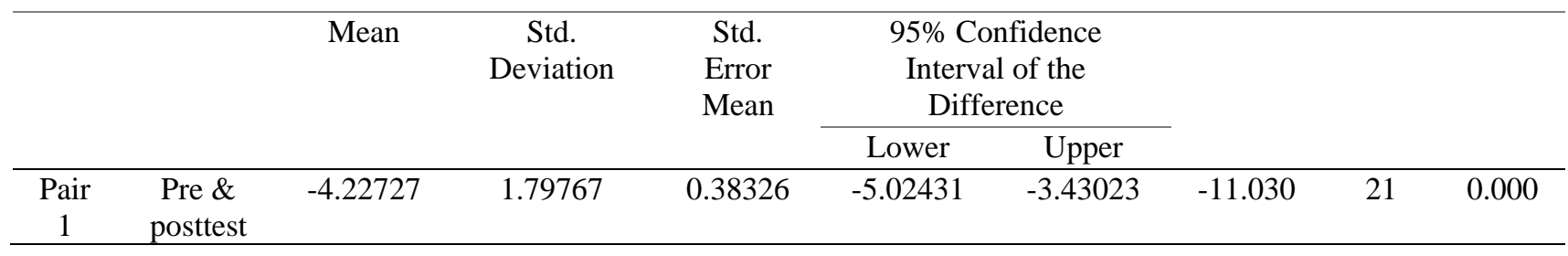

In the same manner, the data of Table 4 presents the $t$ test value for the EG. Based on the data, the $\mathrm{p}$ value $=0.000<0.05$ and thus it indicates perfect meaningful relationship between the performance of the subjects from pre to posttest. In fact, the equation here indicates the effect of metacognitive awareness instruction for the EG who were exposed to the MAI.

\section{Data of the questionnaire}

Table 5

Data on the two questionnaires administration

\begin{tabular}{lcccccc}
\hline & $\mathrm{N}$ & CG mean & Std. Deviation & $\mathrm{N}$ & EG mean & Std. Deviation \\
\hline $\begin{array}{l}\text { Pre } \\
\text { administration }\end{array}$ & 24 & 2.012 & 1.92877 & 22 & 2.0213 & 2.7548 \\
$\begin{array}{l}\text { Post } \\
\text { administration }\end{array}$ & 24 & 2.975 & 2.8337 & 22 & 3.975 & 3.5376 \\
\hline
\end{tabular}

The Table 5 proposes the data of the two administrations of the writing motivation questionnaire. The mean for the first administration of the questionnaire for the EG was estimated to be 2.02 and it increases to 3.97 . The difference between the two means is an 
indication of motivation improvement among the learners in the EG. However, the data for the CG is different. The mean for the first administration of the questionnaire was 2.01 and it increases to 2.9. although we can see some degree of improvement, it is not as high as the motivation among the EG.

Table 6

Paired samples test for questionnaire administrations

\begin{tabular}{|c|c|c|c|c|c|c|c|c|}
\hline & \multicolumn{5}{|c|}{ Paired Differences } & \multirow[t]{3}{*}{$\mathrm{t}$} & \multirow[t]{3}{*}{ df } & \multirow{3}{*}{$\begin{array}{l}\text { Sig. (2- } \\
\text { tailed) }\end{array}$} \\
\hline & \multirow[t]{2}{*}{ Mean } & \multirow[t]{2}{*}{$\begin{array}{c}\text { Std. } \\
\text { Deviation }\end{array}$} & \multirow[t]{2}{*}{$\begin{array}{l}\text { Std. } \\
\text { Error } \\
\text { Mean }\end{array}$} & \multicolumn{2}{|c|}{$\begin{array}{l}95 \% \text { Confidence } \\
\text { Interval of the } \\
\text { Difference }\end{array}$} & & & \\
\hline & & & & Lower & Upper & & & \\
\hline $\begin{array}{l}\text { PRE - POST } \\
\text { administrations } \\
\text { for EG }\end{array}$ & -0.91643 & 2.10878 & 0.56359 & -2.13400 & 0.30114 & -1.626 & 21 & 0.028 \\
\hline $\begin{array}{c}\text { PRE- POST } \\
\text { administrations } \\
\text { for CG }\end{array}$ & -0.26467 & 0.98571 & 0.25451 & -0.81054 & 0.28120 & 1.040 & 23 & 0.316 \\
\hline
\end{tabular}

The Table 6 shows that there is meaningful relationship between the two administrations of the questionnaires for the $\mathrm{EG}, \mathrm{p}$ value $=0.028<0.05$, but this is not true for the $\mathrm{CG}$, since the $\mathrm{p}$ value $=0.316>0.05$. It can be concluded that MAI had positive effect on the writing motivation of the learners in the EG.

Table 7

Correlational between levels and motivation (CG)

\begin{tabular}{cccc} 
Variables & $\begin{array}{c}\text { Pearson } \\
\text { Correlation }\end{array}$ & P-Value & N \\
\hline Levels and Motivation to Writing & 0.674 & 0.221 & 24
\end{tabular}

Table 8

Correlational between levels and motivation (EG)

\begin{tabular}{cccc} 
Variables & $\begin{array}{c}\text { Pearson } \\
\text { Correlation }\end{array}$ & P-Value & N \\
\hline Level and Motivation to Writing & 0.755 & 0.004 & 22
\end{tabular}

Tables 7 and 8 present the data of the relationship between the two levels of the learners and their motivation. Based on the data, it can be inferred that there is meaningful relationship between the two levels and their degree of motivation. (Table 7) presents the data of the CG. The $\mathrm{p}$ value was estimated to be $0.221>0.05$ and it indicates no relationship. On the other hand, (Table 8) demonstrated the data of EG. It shows that there is meaningful relationship between the level motivation: $p$ value $=0.004<0.05$. From the given data, it can be inferred that the two level have two different degree of motivation. In other words, the two level of the EG 
demonstrated differently in terms of their responses towards motivation in learning writing.

\section{Discussion}

Both descriptive and inferential data supported the effective use of MAI in the writing class and that the procedures significantly led to the intrinsic motivation development of the learners. In other words, the achievements supported the fact that the learners could improve their writing skill as well as their intrinsic motivation that could be a factor for the learners to write actively. Moreover, the difference between the responses of the two levels to the motivation questionnaire proved to be meaningful. In other words, intrinsic motivation is an effective factor that can help the learners improve their writing skills more than the learners who are demotivated. Based on achievement of the study, teachers are recommended to employ some procedures that would impact the language skills of the learners by addressing their special needs of their students as well as assisting them to feel more motivated. As it was discussed before, writing is one of the most demotivating activities among the EFL learners in Iran (Hyland, 2002) and in other countries, (Deci et al., 1999); and it is very essential for the language teachers to employ the teaching techniques and procedures that can both improve the given skill as well as motivating them to be an active and interested learner.

Various studies have shown that emotional and social factors are important and decisive in second language learning. As students' attitudes and motivations become more internalized, their desire to continue learning the language increases and their sense of competence in the language under study increases (Skehan, 1989; Riding \& Rayner, 2000; Ehrman, 1996; Dörnyei, 2005; Leaver et al., 2005). Various studies have also shown that English language learning strategies, including metacognitive awareness, affect English language learning, and the use of these strategies is one of the characteristics of successful learners (Dornyei, 2001; Noels, 2009; Noels et al., 2000; Wu, 2003). Metacognitive awareness is important for learning English. English language learners can have the most successful learning when they have a good insight into their personal abilities. If their level of metacognitive awareness improves, their learning outcomes will also improve. The more a learner learns about effective learning strategies and the limitations of their learning and memory abilities, the more likely they are to succeed in learning English.

\section{Conclusion}

The implementation of MAI in the writing class and instructing the young EFL learners supported the constructive use of these procedures and their impact on the intrinsic motivation of the learners. Based on the study achievements, it can be claimed that to observe any sort of improvement among the learners requires instructors to employ teaching procedures that are effective, goal-oriented, and motivating. In fact, if the learners are provided with enough 
strategy to write and at the same time feel motivated enough, the teaching steps will lead to constructive results. The study achievements are compatible with some studies that were carried out on similar topics. (Jacobs y Paris, 1987) investigated the relationship between motivation, metacognitive knowledge of learning strategies and listening comprehension of Iranian learners of English. They found out that implementing strategies and MAI can lead to better achievements. In the same manner, (Hairston, 1982) investigated the level of Iranian university students' metacognitive listening strategies awareness in learning English by administering MALQ among university students of different majors. The overall result showed that more than $60 \%$ of the participants were fully or considerably aware of their metacognitive listening strategies. It was also found that girls and boys were not different with regard to their general metacognitive awareness of listening strategies. (Salehi y Farzad, 2003) investigated the relationship between metacognitive knowledge, learning conception and learning English among more than three hundred students. In order to carry out the research they used state metacognition inventory which was developed and validated by (Rahimi y Katal, 2013), learning conception interview based on Saljo's study (1979), and a researcher-made English language proficiency test. Results of the study revealed that there is a relationship between metacognitive knowledge, learning conception and learning English.

\section{References}

Bereiter C. \& Scardamalia M. (1987), The psychology of written composition. New Jersey, USA: Lawrence Erlbaum Associates.

Brown A. (1987), Metacognition, executive control, self-regulation, and other more mysterious mechanisms, In F. Weinert \& R. Kluwe (Eds.), Metacognition, motivation, and understanding, New Jersey, USA: Erlbaum.

Brown D. \& Abeywickrama P. (2010), Language Assessment, Principles and Classroom Practices. NY: Pearson.

Brown J. \& Hudson T. (2003), Criterion-referenced Language Testing. London: Cambridge Applied Linguistics.

Brown J. (2005), Testing in Language Programs, A comprehensive Guide to English Language Programs. Singapore: McGraw Hill.

Corsale K. \& Ornstein P. (1980), Developmental changes in children's use of semantic information in recall. Journal of Experimental Child Psychology, 30(5): 231-245.

De Bot K. \& Lowie W. \& Verspoor M. (2005), Second language acquisition: an advanced resource book, New York; London: Routledge.

Deci E. \& Koestner R. \& Ryan R. (1999). A meta-analytic review of experiments examining the effects of extrinsic rewards on intrinsic motivation, Psychological Bulletin, 125(6): 

627-668.

Deci E. \& Ryan M. (1985), Intrinsic Motivation and Self-Determination in Human Behaviour. New York: Plenum.

Dornyei Z. (2001), Teaching and researching motivation, Harlow: Pearson Education, 15(3): 169-180.

Dörnyei Z. (2005), The Psychology of the Language Learner: Individual Differences in Second Language Acquisition. Mahwah, New Jersey: Lawrence Erlbaum Associates, Inc., Publishers, 17(3): 149-163.

Ehrman M. (1996) Understanding Second Language Difficulties. California, U.S.A: Sage Publications, Inc.

Flavell J. (1979), Metacognition and cognitive monitoring: A new area of cognitivedevelopmental inquiry. American Psychologist.

Flavell J. (1987), Speculation about the nature and development of metacognition. In F. Weinert \& R. Kluwe (Eds.), Metacognition, motivation, and understanding, Hillsdale, NJ: Lawrence Erlbaum.

Fulcher G. \& Davidson F. (2007), Language Testing and Assessment, an advanced resource book. GB: Routledge.

Garner R. (1988), Metacognition and reading comprehension, Norwood, NJ: Ablex Publishing. Gold D., Hobbs C. \& Berlin J. (2012), , A short history of writing instruction: From ancient Greece to contemporary America, New York: Routledge.

Hacker D. (2009), Definitions and empirical foundations, In D. J. Hacker, J. Dunlosky, \& A. C. Graesser (Eds.), Metacognition in educational theory and practice, Mahwah, NJ: Lawrence Erlbaum Associates, 4(1): 1-24.

Hairston M. (1982), The winds of change: Thomas Kuhn and the revolution in the teaching of writing. College Composition and Communication, 33(5): 76-88.

Hamp-Lyone L. (2000), Fairness in language testing, In Kunnan, A. J. (ed). Fairness and validation in Language Assessment, Studies in Language Testing 9, Cambridge: Cambridge University Press, 4(3): 30-34.

Hartman H. (2001), Developing students' metacognitive knowledge and skills. In H.J. Hartman Metacognition in learning and instruction: Theory, research and practice, Boston: Kluwer Academic.

Hayes J. \& Flower L. (1980), Identifying the organization of writing processes. In L. Gregg \&

E. Steinberg (Eds.), Cognitive processes in writing, Hillsdale, NJ: Erlbaum.

Heaton J. (1988), Writing English Language Tests, Longman Handbook for Language Teachers, London: Longman Group UK Ltd.

Hidi S. \& Boscolo P. (2007), Writing and motivation, Oxford: Elsevier.

Hyland K. (2002), Teaching and researching writing, New York: Longman. 
Jacobs J. \& Paris S. (1987), Children's metacognition about reading: Issues in definition, measurement, and instruction. Educational Psychologist, (22): 225-278.

Johns A. (1990), L1 composition theories: Implications for developing theories of L2 composition. In B. Kroll (Ed.), Second language writing: Research insights for the classroom, Cambridge: Cambridge University Press, 17(4): 24-36.

Leaver B. \& Ehrman M. \& Shekhtman B. (2005), Achieving Success in Second Language Acquisition. Cambridge: Cambridge University Press, 17(3): 149-163.

Mohanty S. (2007). Lifelong and adult education, New Delhi: Ashish Publishing House, 19(1): 311-320.

Nelson T. \& Narens L. (1990), Metamemory: a theoretical framework and new findings. The Psychology of Learning and Motivation, In G. Bower (Ed.); New York: Academic Press, 26(9): 125-173

Noels K. \& Pelletier L. \& Clement R. \& Vallerland R. (2000), What are you learning a second language? Orientations and self-determination theory. Language Learning, 50(1): 5785.

Noels K. (2009). The internalization of language learning into the self and social identity. In Z. Dornyei \& E. Ushioda (Eds.), Motivation, language identity and the self, Bristol: Multilinual Matters, 12(6): 295-313.

Öz H. (2005), Metacognition in foreign / second language learning and teaching, Hacettepe University Journal of Education, 29(3):147-156.

Rahimi M. \& Katal M. (2013), The impact of metacognitive instruction on EFL learners' listening comprehension and oral language proficiency. Journal of Teaching Language Skills, 5(2): 69-90.

Renee Payne A. (2007), Development of the Academic Writing Motivation Questionnaire, (Master's thesis), Unpublished Dissertation, University of Georgia, 19(5): 130-142.

Riding R. \& Rayner S. (2000), Cognitive styles and learning strategies: understanding style differences in learning and behaviour. London: David Fulton, 18(1): 78-100.

Salehi R. \& Farzad V. (2003), The relationship between metacognitive knowledge, learning conception and learning English, Journal of Psychology, 7(3): 270-286.

Schneider W. (1985), Developmental trends in the metamemory memory behavior relationship: an integrative review. Metacognition, cognition, and human performance 1, New York: Academic Press, 19(8): 78-99.

Schraw G. \& Denison R. (1994), Assessing Metacognitive Awareness. Contemporary Educational Psychology, 19(2): 460-475.

Schunk D. \& Ertmer P. (1999), Self-regulatory processes during computer skill acquisition: goal and self-evaluative influences. Journal of Educational Psychology, 91(3): 251-260.

Sitko B. (1998), Knowing how to write: Metacognition and writing instruction, In D. J. Hacker, 
J. Donlosky \& A. C. Graesser (Eds.), Metacognition in educational theory and practice, Mahwah, NJ: Erlbaum, 15(6): 93-115.

Skehan P. (1989). Individual Differences in Second Language Acquisition. London: Edward Arnold.

Wong B. (1991), The conceptual perspectives in the connections between reading and writing processes. In A. McKeough \& J. L. Lupart (Eds.), Toward the practice of theory-based instruction. Current cognitive theories (p. 66-93). Hillsdale, NJ: Lawrence Erlbaum, 19(1): 159-170.

Wu X. (2003), Intrinsic motivation and young learners: The impact of the classroom environment. System, 23(1): 32-55. 